\title{
Interdigitating Dendritic Cell Tumor of Submandibular Lymph Node: Case Report and Literature Review
}

\author{
Soroush Felezi $^{1(D)}$, Anahita Nosrati ${ }^{1 *(D)}$, Mohammad Eslami Jouybari ${ }^{2}$ (D), Javane Jafarshad ${ }^{3}$ (id
}

1. Department of Pathology, Imam Khomeini Hospital, Mazandaran University of Medical Sciences, Sari, Iran

2. Gastrointestinal Cancer Research Center, Mazandaran University of Medical Sciences, Sari, Iran

3. Department of Pathology, Cancer Institute, Imam Khomeini Hospital Complex, Tehran University of Medical Sciences, Tehran, Iran

\begin{tabular}{cl}
\hline Information & ABSTRACT \\
\cline { 1 - 1 } Scan to discover online & $\begin{array}{l}\text { Dendritic cells (DCs) are key arms of immune system, which act in antigen } \\
\text { presenting processes, and are considered as a bridge between innate and adaptive } \\
\text { immune responses. DCs are found in both lymphoid and non-lymphoid organs. They } \\
\text { are called interdigitating dendritic cells (IDCs) in secondary lymphoid organs. IDCs }\end{array}$ \\
$\begin{array}{cl}\text { lack lineage surface markers and are positive for S-100 and vimentin. IDC sarcoma } \\
\text { (IDCS) is a very rare neoplasm, which mainly affects lymph nodes, though there are }\end{array}$ \\
reports of extra-nodal involvement. IDCS is thought to have poor prognosis. Although \\
there is no consensus on the treatment modalities, such options as radical surgery, \\
chemotherapy, and radiotherapy are performed depending on severity and site of the \\
lesion. In this study, we present a case of IDCS in a 53-year-old male with a history of \\
Received 14 Jun 2020;
\end{tabular}

Keywords: Dendritic cell, Interdigitating dendritic cell tumor, Lymph node,

$\underline{10.30699 / I J P .2020 .120698 .2411 ~}$ Sarcoma, Submandibular \footnotetext{
Sari, Iran, E-mail: anahita785@gmail.com

Copyright (C) 2021. This is an open-access article distributed under the terms of the Creative Commons Attribution- 4.0 International License which permits Share, copy
}

Corresponding Information:

Anahita Nosrati, Department of Pathology, Imam Khomeini Hospital, Mazandaran University of Medical Sciences, and redistribution of the material in any medium or format or adapt, remix, transform, and build upon the material for any purpose, even commercially.

\section{Introduction}

Dendritic cells (DCs) are accessory cells of immune system and are capable to introduce antigens to T-cells. Interdigitating dendritic cells (IDCs) are a group of DCs which are mainly present in T-cell areas of secondary lymphoid organs like periarteriolar lymphoid sheath (PALS) of spleen and paracortex of the lymph nodes (1). Sarcoma of interdigitating dendritic cells (IDCs) is a rare malignancy mainly characterized by nodal involvement, and limitedly extra-nodal one. In nodal involvement, patients usually refer with lymphadenopathy; but in other organs involvement, the symptoms can manifest as abdominal pain, distension, skin lesions, and respiratory distress depending on the affected site. Fever, night sweats, and weight loss are observed in some patients too $(1,2)$. This malignancy can affect a wide range of ages, but usually the average age of patients is $50-60$ years and there is a little male predominance (3). These cells have no specific markers but are positive for S-100 and vimentin and negative for B and T-cell markers (4). Although there is no consensus on the best treatment modality for IDCS due to its rarity, such treatment options as excision, chemotherapy, and radiation therapy have been applied with different outcomes (5).
In this study, along with a literature review, we report a male patient diagnosed with IDCS with a previous history of basal cell carcinoma (BCC), squamous cell carcinoma (SCC), metatypical carcinoma (MTC), and non-surgical management.

\section{Literature Review}

We reviewed the case reports published from 2015 to 2019. To do so, we searched the Web of Science with the keyword "Interdigitating dendritic cell sarcoma", which resulted in the retrieval of 23 studies with 17 male and 14 female patients (age range: 22-82 years old). Studies with treatment strategies are shown in Table 1. According to the results of the studies, two patients died due to the complications of chemotherapy, one patient died due to subsequent NK/T lymphoma which occurred two years after IDCS, and one patient died of pneumonia. Moreover, death was seen with all three modalities of surgery alone, chemotherapy, and/or radiation therapy. Most patients had lymph node involvement, but extra-nodal sites such as skin, gastrointestinal tract, respiratory, and 
central nervous system (CNS) involvement were also reported.

Table 1. Published cases of interdigitating dendritic cell sarcoma (IDCS) from 2015 to 2019

\begin{tabular}{|c|c|c|c|}
\hline Author & Gender/age of patient & $\begin{array}{c}\text { Location or symptom of the } \\
\text { tumor }\end{array}$ & Treatment modalities \\
\hline $\begin{array}{l}\text { HZ Chen et al. } \\
2019(6)\end{array}$ & Male/ 57-year-old & Right side of neck & $\begin{array}{l}\text { Lymph node dissection, } \\
\text { radiotherapy, chemotherapy } \\
\text { (Nivolumab, doxorubicin, } \\
\text { olaratumab, ipilimumab, } \\
\text { nivolumab, Sirolimus, } \\
\text { pazopanib) }\end{array}$ \\
\hline $\begin{array}{l}\text { Y Kajimoto et } \\
\text { al. } 2019 \text { (7) }\end{array}$ & Female/82-year-old & Right parotid gland & Parotidectomy, radiotherapy \\
\hline $\begin{array}{l}\text { C Zhao et al. } \\
(2019)(8)\end{array}$ & Female/53-year-old & $\begin{array}{c}\text { Spleen (Abdominal pain and } \\
\text { mass) }\end{array}$ & $\begin{array}{c}\text { Splenectomy, chemotherapy } \\
\text { (ABVD, ifosfamide, oxaliplatin) }\end{array}$ \\
\hline $\begin{array}{l}\text { I Madabhavi et } \\
\text { al. } 2018(9)\end{array}$ & Female/35-year-old & Right side of neck & $\begin{array}{c}\text { chemotherapy (CHOP) } \\
\text { Radiotherapy }\end{array}$ \\
\hline $\begin{array}{l}\text { HT Wang et al. } \\
2018(10)\end{array}$ & Male/64-year-old & Right groin & $\begin{array}{l}\text { Chemotherapy (CHOP, } \\
\text { etoposide, ABVD) Radiotherapy }\end{array}$ \\
\hline $\begin{array}{c}\text { Ayako } \\
\text { Sakakibara et } \\
\text { al. } 2^{1018^{1}}(11)\end{array}$ & Male/58-year-old & Left side of neck & $\begin{array}{c}\text { Surgery } \\
\text { Chemotherapy (CHOP) } \\
\text { Radiotherapy }\end{array}$ \\
\hline $\begin{array}{l}\text { Guerra, F et al. } \\
2018(12)\end{array}$ & Female/23-year-old & $\begin{array}{l}\text { jejunum (Abdominal bloating } \\
\text { and discomfort) }\end{array}$ & Surgery \\
\hline $\begin{array}{l}\text { Ki Hwan Hong } \\
\text { et al. } 2018 \text { (13) }\end{array}$ & Female/59-year-old & Left side of neck & Excision \\
\hline \multirow{7}{*}{$\begin{array}{l}\text { Tian Xue et al. } \\
\quad(2018)(3)\end{array}$} & Female/73-year-old & Cheek & Excision \\
\hline & Female/72-year-old & Nasopharynx & Radiotherapy \\
\hline & Male/61-year-old & Left side of neck & Excision \\
\hline & Male/53-year-old & Submandibular lymph node & Excision \\
\hline & Female/65-year-old & Left side of neck & None \\
\hline & Female/46-year-old & Left side of neck & Excision, Radiotherapy \\
\hline & Female/44-year-old & Left side of neck & Chemotherapy \\
\hline $\begin{array}{l}\text { Ninkovic, S et } \\
\text { al. } 2017 \text { (14) }\end{array}$ & Male/49-year-old & Neck lymphadenopathy & $\begin{array}{c}\text { Excision } \\
\text { CHOP chemotherapy } \\
\text { gemcitabine/docetaxel }\end{array}$ \\
\hline $\begin{array}{l}\text { Magro, CM et } \\
\text { al. } 2017 \text { (15) }\end{array}$ & $\begin{array}{l}\text { Male/55-year-old } \\
\text { Male/47-year-old }\end{array}$ & $\begin{array}{l}\text { peri-auricular mass } \\
\text { Back nodule }\end{array}$ & $\begin{array}{l}\text { Excision } \\
\text { Radiotherapy } \\
\text { Excision }\end{array}$ \\
\hline
\end{tabular}




\begin{tabular}{|c|c|c|c|}
\hline Author & Gender/age of patient & $\begin{array}{c}\text { Location or symptom of the } \\
\text { tumor }\end{array}$ & Treatment modalities \\
\hline & & & $\begin{array}{c}\text { Chemotherapy (taxol and } \\
\text { carboplatin) }\end{array}$ \\
\hline $\begin{array}{l}\text { Hwang, SY et } \\
\text { al. } 2017 \text { (16) }\end{array}$ & Female/75-year-old & Neck lymphadenopathy & Chemotherapy (ABVD) \\
\hline \multirow{2}{*}{$\begin{array}{l}\text { Shi, F et al. } \\
2017 \text { (2) }\end{array}$} & Male/40-year- old & Inguinal mass & $\begin{array}{c}\text { Chemotherapy (CHOPE } \\
\text { DHAP) }\end{array}$ \\
\hline & Female/62-year- old & Respiratory symptoms & $\begin{array}{c}\text { Chemotherapy (paclitaxel and } \\
\text { nedaplati) }\end{array}$ \\
\hline $\begin{array}{l}\text { Jianguo Zhu et } \\
\text { al. } 2017 \text { (1) }\end{array}$ & Male/52-year-old & $\begin{array}{c}\text { Pelvic mass (Abdominal } \\
\text { distension) }\end{array}$ & Surgery \\
\hline $\begin{array}{l}\text { Catherine M. } \\
\text { Nguyen and } \\
\text { David } \\
\text { Cassarino, } \\
2016 \text { (17) }\end{array}$ & Male/61-year-old & $\begin{array}{l}\text { Multiple lesions on shoulder } \\
\text { and thigh }\end{array}$ & $\begin{array}{c}\text { chemotherapy (gemcitabine and } \\
\text { docetaxel) }\end{array}$ \\
\hline $\begin{array}{l}\text { Valentina } \\
\text { Lupato et al. } \\
2016(18)\end{array}$ & Male/81-year-old & Submandibular mass & $\begin{array}{l}\text { dissection } \\
\text { Radiotherapy }\end{array}$ \\
\hline $\begin{array}{l}\text { Gregor Hutter } \\
\text { et al. } 2015(19)\end{array}$ & Male/39-year-old & Mild hemiparesis & Surgery \\
\hline $\begin{array}{c}\text { Shan, SJ et al. } \\
2015(20)\end{array}$ & Female/41-year-old & lesion on the shoulder & Excision \\
\hline $\begin{array}{l}\text { Di Liso, E et al. } \\
2015 \text { (21) }\end{array}$ & Male/59 year-old & Axillary lymphadenopathy & $\begin{array}{c}\text { Surgery } \\
\text { Radiotherapy } \\
\text { Chemotherapy (epirubicin, } \\
\text { ifosfamide), BRAF inhibitor }\end{array}$ \\
\hline $\begin{array}{l}\text { O'Malley, DP } \\
\text { et al. } 2015(22)\end{array}$ & Male/54-year-old man & Lymphadenopathy in groin & $\begin{array}{c}\text { Excision } \\
\text { Chemotherapy (R-CHOP, } \\
\text { ifosfamide,carboplatin, } \\
\text { etoposide) }\end{array}$ \\
\hline $\begin{array}{l}\text { C Kyogoku et } \\
\text { al. } 2015(5)\end{array}$ & Male/62-year-old & Several skin lesions & Chemotherapy (ABVD) \\
\hline $\begin{array}{l}\text { Venkata K. } \\
\text { Pokuri } 2015 \\
(23)\end{array}$ & Male/81-year-old & $\begin{array}{l}\text { enlarging and painless left } \\
\text { neck mass }\end{array}$ & Dissection (two times) \\
\hline $\begin{array}{l}\text { Helbig, G et al. } \\
2015 \text { (24) }\end{array}$ & Female/22-year-old & Neck lymphadenopathy & $\begin{array}{c}\text { Excision } \\
\text { Chemotherapy (ABVD) }\end{array}$ \\
\hline
\end{tabular}

\section{Case Presentation}

The patient was a 53-year-old man referred to the Oral and Maxillofacial Surgery Department of a teaching hospital due to a history of neck swelling for seven months. Ultrasound examination revealed an echo-free mass of $24.1 \times 36.4 \mathrm{~mm}$ with regular shape and no adhesions to surrounding skin and at a depth of $3.9 \mathrm{~mm}$ from the skin of the left parotid region with possible diagnosis of benign mass or lymphadenopathy. The patient had photosensitivity and multiple skin lesions from childhood and at the age of 51, and he was diagnosed with BCC of the zygomatic region and lip, MTC of the frontal skin, and keratoacanthoma (KA)-like SCC of nose. Family history was unremarkable. He underwent radical lymph node dissection; in the histopathologic examination, a submandibular mass measured $4 \times 2.5 \times 1$ $\mathrm{cm}$ was found, which was effaced by a malignant mesenchymal tumor with storiform pattern. Neoplastic cells were spindled-shaped with hyperchromatic, pleomorphic nuclei, vesicular chromatin, visible nucleoli, and eosinophilic cytoplasm. Mitosis (about 15 mitosis per $10 \mathrm{HPF}$ ), foci of hemorrhage, and necrosis were also noted. Based on mentioned findings, a primary diagnosis of metastatic malignant spindle cell tumor was made, but immunohistochemical (IHC) studies was suggested for a definitive diagnosis. Review of the hematoxylin and eosin (H\&E)/trichrome-stained slides showed near total effacement of the node structure by fascicle and sheets of the tumor cells sparing follicles and sinuses. The 
tumoral cells were large and pleomorphic with abundant pale eosinophilic cytoplasm and bizarre, grooved nuclei showing some mitotic figures. Just a narrow rim of small lymphocytes was present in the outer aspect of the specimen. Considering the possible diagnosis, a wide IHC panel (Table 2) was performed and subsequently, the diagnosis of IDC sarcoma (tumor) was established. To detect whether the tumor is localized or has spread, contrast-enhanced spiral CT of the head and neck, chest, and abdominopelvic was ordered and no pathologic lesions and lymphadenopathy were observed. Therefore, no chemo-radiation was prescribed for the patient. Currently, ultrasound follow-up is on the process for the patient at the 3-month intervals ; the results has indicated no sign of recurrence as solid or cystic mass in neck tissue, and the patient is doing well.

Table 2. Markers used in this IHC study.

\begin{tabular}{|c|c|c|c|c|c|c|c|c|c|}
\hline \multicolumn{10}{|l|}{ Positive } \\
\hline Marker & S100 & & Vimentin & \multicolumn{2}{|c|}{ CD68 } & Desmin & \multicolumn{3}{|c|}{$\mathrm{CD} 45$} \\
\hline Pattern & Diffuse & & Intense & \multicolumn{2}{|c|}{ Focal } & scattered weak & \multicolumn{3}{|c|}{ in remnant lymphocytes } \\
\hline \multicolumn{10}{|l|}{ Negative } \\
\hline Marker & CD34 & $\mathrm{CD} 3$ & CD30 & CD56 & BCL2 & HMB45 & MNF116 & P63 & Melan A \\
\hline
\end{tabular}

\section{Discussion}

IDCS is a rare hematologic malignancy with the highest prevalence reported in lymph nodes, though tumor can occur in extra-nodal sites such as lung, colon, and skin. For this reason, depending on the site of the lesion, different symptoms can take place; in head and neck areas the appearance of a mass or lymphadenopathy, in gastrointestinal tract and spleen, abdominal mass, distension, and pain $(1,8)$, and in lung and airway it can lead to respiratory symptoms (25). Due to fever, lymphadenopathy, and respiratory symptoms, suspicion of lymphoma can make diagnosis a challenging issue. Final diagnosis is based on histopathologic examination and IHC studies. Microscopic features of IDCS include spindled, ovoid, and epithelioid cells with eosinophilic cytoplasm and occasional prominent nucleoli, showing storiform, nodular, and fascicular growth patterns. Mitotic figures and necrosis may also be present $(2,3)$. Infiltration of the stroma with inflammatory cells like plasma cells and lymphocytes can also be observed. Tumoral cells are positive for S100, vimentin, CD68 (26) and are negative for CD1a, CD34, CD35, HMB45, Melan-A, CD21, and lineage markers for B- and T-cells (27). Differential diagnoses include non-hematologic (like melanoma, spindle cell SCC, and several mesenchymal neoplasms) and hematologic neoplasms (follicular DC sarcoma, Langerhans cell histiocytosis, and fibroblastic reticular cell tumor). There is still no consensus on the choice of treatment for this malignancy. However, considering the stage of the disease and whether the lesion is localized, or it has spread, different modalities including surgery, chemotherapy, and radiation are applied. Chemotherapies usually contain CHOP regimen (Cyclophosphamide, Doxorubicin, Vincristine, and Prednisone), ABVD regimen (Doxorubicin, Bleomycin, Vinblastine, and Dacarbazine), DHAP regimen (Cisplatin, Cytarabine, and Dexamethasone), taxol, carboplatin, ifosfamide, and oxaliplatin $(2,8$, 15). We chose surgical dissection and carefully monitored the patient because the lesion was localized. There are reports of recurrence of tumor and death despite chemotherapy. Appropriate response to treatment with ABVD regimen has also been observed. Potential side effects should also be considered when choosing chemotherapy, as chemotherapy-induced liver injury which can be fatal.

The etiology of IDCS is not yet fully understood due to its rarity. BRAF mutations (a kinase involved in cell signaling) which frequently occur in some hematologic neoplasms like Langerhans cell histiocytosis (LCH) and hairy cell leukemia (HCL) are found in IDCS too $(21,28)$. Bailleux et al. (29) applied initial low dose BRAF inhibitor (Vemurafenib) to treat a male patient with relapsed HCL, which led to complete remission (30). Eight months later and due to the relapsed disease, vemurafenib was re-administrated and complete hematologic response was achieved (29). This treatment was also prescribed by Di Liso et al. for their IDCS patient and resulted in tumor shrinkage but toxicity was also noted (21). Programmed death-ligand 1 (PD-L1) is an immune inhibitory protein which suppresses tumor specific immune responses by binding to PD1 on activated T cells. Sakakibara et al. showed membranous and cytoplasmic expression of PD-L1 on IDCS cells of a patient who died from a progressive disease. This is important in terms of how tumoral cells evade detection by the immune cells and potential therapeutic targets (11).

An interesting study performed whole exome sequencing (WES) on the blood and tumor specimens of an IDCS patient; the results showed that alteration in DNA polymerase theta (POLQ) and folliculin 
interacting protein 1 (FNIP1) genes may be involved in malignant potential of IDCs (13). IDCS has also been developed in patients who received organ transplantation; so, the question is raised if immunosuppressive agents could be as causes of IDCS (3). Although medical history in several patients is unremarkable, presence of a previous or simultaneous malignancy is observed in some reports. The present patient had a history of multiple skin cancers. Rosenberg et al. presented a female patient with BCC of back skin (31), and Lee et al. reported an IDCS patient with an unknown type of skin cancer (32). So, it is unclear whether previous therapies for cancer have triggered IDCS development or not. There are also observations of increased risk of other malignancies in the following years in IDCS patients. Therefore, it is important to monitor patients even after the malignancy is treated. Finally, our patient responded well to surgery due to the localization of the lesion, but given that many patients have been reported to present with progressive disease and die of IDCS, a chemoradiation therapy should be considered if the disease is multifocal and other organs are involved.

\section{Acknowledgements}

The authors would like to express their gratitude towards all who helped in the improvement of this paper.

\section{Financial Support}

All authors have not received any financial support from any person or organization for this study.

\section{Conflict of Interest}

The authors had no conflict of interest to report.

\section{References}

1. Zhu J, Su S, Zhou J, Li H. Interdigitating dendritic cell sarcoma presenting in the sigmoid colon mesentery: A case report and literature review. Medicine (Baltimore). 2017;96(16):e6210. [DOI:10.1097/MD.0000000000006210] [PMID] [PMCID]

2. Shi F, Song Q, Wang L, Gao Y, Chang H. Diffuse lesion and necrosis tied to poorer prognosis of interdigitating dendritic cell sarcoma: cases report and a pooled analysis. Sci Reports. 2017;7(1):667. [DOI:10.1038/s41598-017-00719-2] [PMID] [PMCID]

3. Xue $T$, Jiang $X N$, Wang WG, Zhou XY, Li XQ. Interdigitating dendritic cell sarcoma: Clinicopathologic study of 8 cases with review of the literature. Ann Diagn Pathol. 2018;34:155-60. [DOI:10.1016/j.anndiagpath.2018.03.008] [PMID]

4. Chang KL, Arber DA, Weiss LM. Lymph Nodes. In: Weidner N, Cote RJ, Suster S, Weiss LM, editors. Modern Surgical Pathology. Philadelphia: W.B.
Saunders; 2009. p. 1431-511. [DOI:10.1016/B978-14160-3966-2.00041-2]

5. Kyogoku C, Seki M, Ogawa S, Miyamoto K, Ito Y, Kurita N, et al. Complete Remission in Systemic Skin Interdigitating Dendritic Cell Sarcoma after ABVD Chemotherapy. J Clin Exp Hematop. 2015;55(1):33-7. [DOI:10.3960/jslrt.55.33] [PMID]

6. Chen H-Z, Bonneville R, Yu L, Wing MR, Reeser JW, Krook MA, et al. Genomic characterization of metastatic ultra-hypermutated interdigitating dendritic cell sarcoma through rapid research autopsy. Oncotarget. 2019;10(3):277. [DOI:10.18632/oncotarget.26352] [PMID] [PMCID]

7. Kajimoto Y, Otsuki N, Teshima M, Morinaga Y, Itoh T, Nibu K-I. Successful Treatment of Interdigitating Dendritic Cell Sarcoma Presenting as Multiple Parotid Tumors. Acta Oto-Laryngologica Case Reports. 2019;4(1):26-9.

[DOI:10.1080/23772484.2019.1635887]

8. Zhao C, Xie X, Gai DZ, Wu D, Xin H, Yang T. Interdigitating dendritic cell sarcoma of the spleen with hepatic failure after chemotherapy: A case report. Medicine (Baltimore). 2019;98(19):e15535. [DOI:10.1097/MD.0000000000015535] [PMID] [PMCID]

9. Madabhavi I, Patel A, Modi G, Anand A, Panchal H, Parikh S. Interdigitating dendritic cell tumor: A rare case report with review of literature. J Cancer Res Ther. 2018;14(3):690-3. [DOI:10.4103/0973-1482.183189] [PMID]

10. Wang HT, Xu HY, Zhang R, Liu ZG, Zhang GJ. Interdigitating dendritic cell sarcoma located in the groin: a case report and literature review. J Int Med Res. 2018;46(11):4791-9. [DOI:10.1177/0300060518792444] [PMID] [PMCID]

11. Sakakibara A, Takahashi E, Ishikawa E, Kohno K, Asano N, Nakamura S. Neoplastic PD-L1 expression on interdigitating dendritic cell sarcoma: A supplementary study of a case report. Pathol Int. 2018;68(10):577-8. [DOI:10.1111/pin.12711] [PMID]

12. Guerra F, Vegni A, Perna F, Messerini L, Coratti A. Primary jejunal interdigitating dendritic cell sarcoma. Ann Diagn Pathol. 2018;32:1-3. [DOI:10.1016/j.anndiagpath.2017.08.001] [PMID]

13. Hong KH, Song S, Shin W, Kang K, Cho C-S, Hong YT, et al. A case of interdigitating dendritic cell sarcoma studied by whole-exome sequencing. Genes \& Genomics. 2018;40(12):1279-85. [DOI:10.1007/s13258-018-0724-y] [PMID]

14. Ninkovic $\mathrm{S}$, Cole-Sinclair MF. Interdigitating dendritic cell sarcoma: diagnostic pitfalls, treatment challenges and role of transdifferentation in pathogenesis. Pathology. 2017;49(6):643-6 [DOI:10.1016/j.pathol.2017.05.015] [PMID]

15. Magro CM, Olson LC, Nuovo G, Solomon GJ. Primary cutaneous interdigitating dendritic cell sarcoma is a morphologic and phenotypic simulator of poorly differentiated metastatic melanoma: a report of 2 cases and review of the literature. Ann Diagn Pathol. 2017;30:59-65. [DOI:10.1016/i.anndiagpath.2017.02.008] [PMID] 
16. Hwang SY, Woo IS, Chong Y, Kang CS, Han CW, Jung YH. An unusual case of metachronous NK/T cell lymphoma and interdigitating dendritic cell sarcoma. Blood Res. 2017;52(3):224-7. [DOI:10.5045/br.2017.52.3.224] [PMID] [PMCID]

17. Nguyen CM, Cassarino D. Primary Cutaneous Interdigitating Dendritic Cell Sarcoma: A Case Report and Review of the Literature. Am J Dermatopathol. 2016;38(8):628-31.

[DOI:10.1097/DAD.0000000000000618] [PMID]

18. Lupato V, Romeo S, Franchi A, Mantovani M, Dei Tos AP, Tirelli G, et al. Head and Neck Extranodal Interdigitating Dendritic Cell Sarcoma: Case Report and Review of the Literature. Head Neck Pathol. 2016;10(2):145-51. [DOI:10.1007/s12105-015-0627z] [PMID] [PMCID]

19. Hutter G, Hofer S, Tzankov A, Kothbauer KF. Intracranial Interdigitating Dendritic Cell Sarcoma: First Case Report. Neurosurgery. 2015;77(6):E979-83. [DOI:10.1227/NEU.0000000000000925] [PMID]

20. Shan SJ, Meng LH, Lu R, Guo Y. Primary Cutaneous Interdigitating Dendritic Cell Sarcoma: A Case Report and Review of the Literature. Am J Dermatopathol. 2015;37(8):639-42. [DOI:10.1097/DAD.0000000000000222] [PMID]

21. Di Liso E, Pennelli N, Lodovichetti G, Ghiotto C, Dei Tos AP, Conte $\mathrm{P}$, et al. Braf mutation in interdigitating dendritic cell sarcoma: a case report and review of the literature. Cancer Biol Ther. 2015;16(8):1128-35. [DOI:10.1080/15384047.2015.1057359] [PMID] [PMCID]

22. O'Malley DP, Agrawal R, Grimm KE, Hummel J, Glazyrin A, Dim DC, et al. Evidence of BRAF V600E in indeterminate cell tumor and interdigitating dendritic cell sarcoma. Ann Diagn Pathol. 2015;19(3):113-6. [DOI:10.1016/j.anndiagpath.2015.02.008] [PMID]

23. Pokuri VK, Merzianu M, Gandhi S, Baqai J, Loree TR, Bhat S. Interdigitating dendritic cell sarcoma. J Natl Compr Canc Netw. 2015;13(2):128-32. [DOI:10.6004/jncen.2015.0020] [PMID]

24. Helbig G, Wichary R, Pająk J, Budny M, Makowska $M$, Machura K, et al. Sustained remission after ABVD treatment for interdigitating dendritic cell sarcoma. Contemporary Oncol. 2015;19(1):83. [DOI:10.5114/wo.2014.43974] [PMID] [PMCID]
25. Lee S-y, Lee SR, Chang WJ, Kim HS, Kim BS, Kim IS. Successful treatment of disseminated interdigitating dendritic cell sarcoma with adriamycin, bleomycin, vinblastine, and dacarbazine chemotherapy. The Korean journal of hematology. 2012;47(2):150-3. [DOI:10.5045/kjh.2012.47.2.150] [PMID] [PMCID]

26. Uluoglu O, Akyurek N, Uner A, Coskun U, Ozdemir A, Gokcora N. Interdigitating dendritic cell tumor with breast and cervical lymph-node involvement: a case report and review of the literature. Virchows Archiv : an international journal of pathology. 2005;446(5):54654. [DOI:10.1007/s00428-005-1209-3] [PMID]

27. Lin P, Medeiros LJ. Hematopoietic Lesions. In: Gnepp DR, editor. Diagnostic Surgical Pathology of the Head and Neck. Philadelphia: W.B. Saunders; 2009. p. 93374. [DOI:10.1016/B978-1-4160-2589-4.00013-9] [PMID]

28. O'Malley DP, Agrawal R, Grimm KE, Hummel J, Glazyrin A, Dim DC, et al. Evidence of BRAF V600E in indeterminate cell tumor and interdigitating dendritic cell sarcoma. Annals of Diagnostic Pathology. 2015;19(3):113-6.

[DOI:10.1016/j.anndiagpath.2015.02.008] [PMID]

29. Bailleux C, Robert G, Ginet C, Re D, Thyss A, Sudaka I, et al. Successful re-treatment of a relapsed V600E mutated HCL patient with low-dose vemurafenib. Oncoscience. 2015;2(1):44-9. [DOI:10.18632/oncoscience.111] [PMID] [PMCID]

30. Peyrade F, Re D, Ginet C, Gastaud L, Allegra M, Ballotti $\mathrm{R}$, et al. Low-dose vemurafenib induces complete remission in a case of hairy-cell leukemia with a V600E mutation. Haematologica. 2013;98(2):e20-2.

[DOI:10.3324/haematol.2012.082404] [PMID] [PMCID]

31. Rosenberg SA, Niglio SA, Jo VY, Goydos JS. Interdigitating dendritic cell sarcoma presenting in the skin: diagnosis and the role of surgical resection, chemotherapy and radiotherapy in management. Rare tumors. 2014;6(4):5573. [DOI:10.4081/rt.2014.5573] [PMID] [PMCID]

32. Lee JC, Christensen T, O'Hara CJ. Metastatic Interdigitating Dendritic Cell Sarcoma Masquerading as a Skin Primary Tumor: A Case Report and Review of the Literature. Am J Dermatopathol. 2009;31(1):8893. [DOI:10.1097/DAD.0b013e31818fb7e4] [PMID]

\section{How to Cite This Article}

